\title{
PENGARUH PENDIDIKAN KESEHATAN METODE STRATAGEM DENGAN MEDIA AUDIOVISUAL TERHADAP PENGETAHUAN KESEHATAN REPRODUKSI REMAJA
}

\section{(THE EFFECT OF HEALTH EDUCATION THROUGH AUDIOVISUAL MEDIA STRATAGEM METHOD TOWARD THE KNOWLEDGE OF TEENAGE REPRODUCTIVE HEALTH)}

\author{
Reza Riyady Pragita ${ }^{1 *}$, Retno Purwandari ${ }^{2}$, Lantin Sulistyorini ${ }^{3}$ \\ ${ }_{1,2,3}$ Fakultas Keperawatan Universitas Jember \\ J1. Kalimantan No. 37 Kampus Tegal Boto Jember Telp/Fax. (0331) 323450 \\ *e-mail: rezariyadypragita1142@gmail.com
}

\begin{abstract}
ABSTRAK
Pendidikan kesehatan reproduksi melalui cooperative learning tipe group cooperative game stratagem media audiovisual merupakan inovasi dalam pemberian pesan-pesan kesehatan dalam upaya peningkatan derajat kesehatan. Tujuan dari penelitian ini adalah untuk menganalisis pengaruh pemberian pendidikan kesehatan melalui metode stratagem media audiovisual terhadap tingkat pengetahuan kesehatan reproduksi pada remaja dan enganalisis perbedaan pengaruh dari peberian pendidikan kesehatan etode stratage . Variabel penelitian disini adalah pendidikan kesehatan dengan metode stratagem media audiovisual dan pendidikan kesehatan metode ceramah sebagai variabel independent. Variabel dependent dalam penelitian ini adalah tingkat pengetahuan kesehatan reproduksi remaja. Penelitian ini melibatkan 15 orang sebagai kelompok eksperiment, dan 15 orang sebagai kelompok kontrol dengan menggunakan proporsional stratified random sampling. Uji statistik yang digunakan adalah Wilcoxon dan Mann Whitney. Hasil data yang p nilai 0,014 dan 0,016 $(\alpha<0,05)$. Hasil penelitian ini menyatakan bahwa ada pengaruh yang signifikan antara pendidikan kesehatan melalui metode stratagem media audiovisual pada pengetahuan remaja mengenai kesehatan reproduksi dan terdapat perbedaan pengaruh dalam pendidikan kesehatan melalui metode stratagem media audiovisual dan metode konvensional ceramah. Kesimpulan dari penelitian ini bahwa metode straragem mampu meingkatka pengetahuan remaja tentang kesehatan reproduksi. Rekomendasi dari penelitian ini menunjukkan bahwa dalam memberikan pendidikan kesehatan terutama kesehatan reprodksi pada remaja diperlukannya inovasi yang mampu mengajak remaja berperan aktif dalam pendidikan kesehatan salah satunya dengan menggunakan metode kooperatif seperti stratagem dan media audiovisual.

Kata kunci : Remaja, Pendidikan Kesehatan, Kesehatan Reproduksi.
\end{abstract}

\section{ABSTRACT}

Teenagers have experienced changes in biological, psychological and social aspects. Teenagers are lacking of the knowledge regarding reproductive health. The purpose of this research was to analyze the effect of health education through audiovisual media stratagem method toward the knowledge of teenage reproductive health at SMPN 14 Jember. This research involved 15 individuals who served as the experiment group, and 15 individuals who served as the controlgroup by using proportional stratified random sampling. The statistical test used was Wilcoxon and Mann Whitney. Results of the data is p value of 0.014 and $0.016(\alpha<0.05)$. The conclusion of this research stated that there is a significant effect 
between health education through audiovisual media stratagem method on the knowledge of teenagers in SMPN 14 Jember regarding reproductive health and the variance in the effect of health education through audiovisual media stratagem method and conventional methods. Recommendations of this research suggest that teenagers create reproductive health groups that play an active role in the prevention of teenagers' reproductive health issues by using cooperative methods.

Keywords: Teenagers, Health Education, Reproductive Health

\section{PENDAHULUAN}

Remaja dalam masa perkembangannya terjadi banyak perubahan, baik secara biologis, psikologis maupun kognitif, yang pada umumnya menjadi lebih cepat pematangan fisik dari pada proses pematangan kejiwaan atau psikososial dari remaja. Remaja seringkali kekurangan informasi dasar mengenai kesehatan reproduksi, dan keterbatasan dalam mengakses pelayanan kesehatan reproduksi serta terjamin kerahasiaannya (Depkes, 2008; BKKBN, 2011). Banyak remaja terlibat dalam perilaku seksual berisiko pada kesehatan yang tidak diinginkan. Hasil penelitian, diperkirakan 8.300 remaja di 40 negara melaporkan ke $C D C$ memiliki infeksi $H I V$ pada tahun 2009, hampir setengah dari 19 juta PMS baru setiap tahun diantaranya remaja. Lebih dari 400.000 gadis remaja berusia 15-19 tahun melahirkan pada tahun 2009 (CDC, 2013). Hasil Studi Pendahuluan di Dinas Kesehatan Kabupaten Jember (2014), Puskesmas Sumbersari merupakan puskesmas yang melaporkan kasus kesehatan remaja secara rutin ke kabupaten Jember dengan sasaran kesehatan reproduksi remaja dalam sekolah adalah 13.041 remaja dengan 4932 diantaranya adalah remaja usia 10-14 tahun yakni remaja awal. Hasil studi pendahuluan di Puskesmas Sumbersari (2014), jumlah total peserta didik di SMP Negeri 14 Jember tahun 2015 adalah 437 peserta didik dengan 3 siswi mengundurkan diri karena menikah di usia dini dan 1 orang meninggal dunia. Hasil data-data yang didapatkan, ternyata masih kurangnya informasi mengenai kesehatan reproduksi remaja pada peserta didik di SMP Negeri 14 Jember. Upaya yang mampu menerangkan pengetahuan mengenai kesehatan reproduksi pada remaja adalah melalui pendidikan kesehatan. Perawat sebagai pemberi layanan asuhan keperawatan memiliki peran sebagai pendidik (educator). Perawat memiliki fungsi memberikan pelayanan serta meningkatkan kesehatan individu dan memberikan pendidikan kesehatan kepada populasi remaja sekolah, termasuk tentang kesehatan reproduksi remaja (Nursalam, 2008). Pendidikan kesehatan tidak lepas halnya dari proses belajar mengajar. Strategi yang berkembang dan mampu meningkatkan motivasi, pengetahuan, dan perubahan sikap pada peserta didik terhadap sebuah pembelajaran.

Stratagem merupakan teknik permainan belajar akademik yang dikembangkan oleh Bell Gredler pada tahun 1994 (Susilana dan Riyana, 2009). Metode stratagem sesuai dengan tahap perkembangan kognitif remaja, dimana remaja telah mencapai puncak berpikir kognitif, yakni remaja telah mencapai periode operasional formal.Metode mampu meningkatkan pengetahuan, namun diperlukannya media sebagai penunjang dalam performa dalam proses belajar mengajar. Salah satu media yang dapat dipergunakan saat ini adalah media audiovisual. Penggunaan media yang menyingkronkan dua media yakni media audio dan media visual yang dapat menimbulkan komunikasi dua arah antara pendidik dan peserta didik dalam proses belajar mengajar. Kelebihan media video adalah memberikan pesan yang dapat 
diterima lebih merata, lebih baik untuk menerangkan sebuah proses, mengatasi keterbatasan ruang dan waktu, lebih realistis, dapat diulang-ulang dan memberikan kesan yang mendalam (Arikunto, 2006).

Pendidikan kesehatan reproduksi melalui cooperative learning tipe group cooperative game: stratagem media audiovisual merupakan inovasi dalam pemberian pesan-pesan kesehatan dalam upaya peningkatan derajat kesehatan. Maka peneliti memiliki hipotesis bahwa ada pengaruh pemberian Pendidikan Kesehatan mengguanakan Metode Stratagem dengan media audiovisual terhadap tingkat pengetahuan kesehatan reproduksi remaja dan terdapat perbedaan pengaruh antara pemberian Pendidikan Kesehatan mengguanakan Metode Stratagem dengan media audiovisual dan pemberian Pendidikan Kesehatan mengguanakan Metode Konvensional terhadap tingkat pengetahuan kesehatan reproduksi remaja.

\section{METODE}

Jenis penelitian yang dilakukan adalah penelitian quasi eksperiment design pendekatan non-equivalent control group. Populasi dalam penelitian ini adalah semua remaja di SMP Negeri 14 Jember yang berjumlah 437 remaja. Tekhnik pengambilan sampel yang digunakan dalam penelitian ini adalah Proportional stratified random sampling dengan jumlah sampel sebanyak 30 sampel dengan 15 remaja kelompok kontrol dan 15 remaja kelompok eksperiment dengan kriteria inklusi siswa berstatus aktif di SMP N 14 Jember, brusia remaja awal mengikuti proses pendidikan kesehatan dari awal sapai akhir, sudah mengalami pubertas dan kriteria eksklusi yaitu mengundurkan diri dan tidak mengikut proses pendidikan kesehatan sesuai prosedur.

Uji statistik yang digunakan adalah wilcoxon rank test untuk menguji perbedaan tingkat pengetahuan remaja sebelu dan sesudah diberikan perlakuan pendidikan kesehatan dan mann withney untuk menguji perbedaan hasil antara kelompok perlakuan dan kelompok kontrol dengan tingkat kepercayaan 95\% ( $\alpha<$ $0,05)$.

Peneitian ini mengunakan alat ukur kuesioner yang dkutip dari BKKBN (2011) dan dimodifikasi menjadi Hasil penilaian ini diklasifikasikan menjadi tiga kategori yaitu baik (>76\%), cukup (56-76\%), dan kurang (<56\%) (Arikunto, 2006). Penelitian dilaksanakan di SMP Negeri 14 Jember yang terletak di Jalan Koptu Berlian No. 14 Jember, Kecamatan Sumbersari Kabupaten Jember Provinsi Jawa Timur. Pengambilan data pretest dilakukan serentak bersama dengan inform consent yang dilakukan pada tanggal $7 \mathrm{Mei}$ 2015, dilanjutkan dengan penjelasan mengenai penelitian selaa 50 menit. Pada hari ke dua dilanjukan dengan pendidikan kesehatan dengan materi Kesehatan Reproduksi Remaja selama 200 menit pada masing-masing kelompok. Pada kelompok perlakuan dilakukan pendidikan kesehatan metode Stratagem dan media audiovisual. Pada control dilakukan metode konvensional ceramah. Pengambilan data post test pada tanggal 15 Mei 2015. Berikut skema pendidikan kesehatan metode stratagem media audiovisual.

Persiapan:

Remaja dibagi ke dalam kelompok kecil berjumlah 4-5 orang;

Pemateri berperan sebagai Banker;

Setiap kelompok diberikan modal yang sama;

Peramainan Stratagem

Peneliti menampilkan video tentang kesehatan reproduksi remaja;

Setelah melihat video, setiap klompok mendapat 1 pertanyaan ingatan, 1 pertanyaan aplikasi, dan 2 pertanyaan analisis;

Setiap kelompok diberikan kesempatan melakukan taruhan dari modal yang diberikan;

Setiap kelompok diberikan kesempatan berdiskusi maksimal 2 menit sebelum menjawab pertanyaan;

Apabila jawaban benar, maka kelompok berhak mendapat kelipatan dari taruhannya;

Apabila kelompok salah atau tidak mampu menjawab, maka dipersilahkan kelompok lain untuk menjawab dan mendapatkan taruhan yang telah ditaruhkan oleh kelompok sebelumnya.

Terakhir, pemateri bertanggung jawab menjelaskan dan memberikan tambahan- 
Gambar 1. Skema Pendidikan Kesehatan Metode Stratagem Media Audiovisual

\section{HASIL}

\section{Pengetahuan remaja tentang kesehatan reproduksi remaja sebelum dan sesudah diberikan di SMP Negeri 14 Jember}

Tabel 1. Pengetahuan Remaja Tentang Kesehatan Reproduksi Remaja Sebelum Dan Sesudah

\begin{tabular}{|c|c|c|c|c|c|c|}
\hline \multirow{2}{*}{\multicolumn{2}{|c|}{ Pengetahuan }} & \multicolumn{2}{|c|}{ Sebelum } & \multicolumn{2}{|c|}{ Sesudah } & \multirow[t]{2}{*}{$p$ value } \\
\hline & & $\mathrm{n}$ & $\%$ & $n$ & $\%$ & \\
\hline \multirow{4}{*}{$\begin{array}{l}\text { Kelo } \\
\text { mpok } \\
\text { Strata } \\
\text { gem } \\
\text { audio } \\
\text { visual }\end{array}$} & Kurang & 4 & 26.7 & 0 & 0 & \multirow{4}{*}{0,014} \\
\hline & Cukup & 10 & 66.7 & 12 & 80 & \\
\hline & Baik & 1 & 6.7 & 3 & 20 & \\
\hline & Total & 15 & 100 & 15 & 100 & \\
\hline \multirow{4}{*}{$\begin{array}{l}\text { Kelo } \\
\text { mpok } \\
\text { ceram } \\
\text { ah }\end{array}$} & Kurang & 5 & 33.3 & 3 & 20 & \multirow{4}{*}{0,083} \\
\hline & Cukup & 10 & 66.7 & 12 & 80 & \\
\hline & Baik & 0 & 0 & 0 & 0 & \\
\hline & Total & 15 & 100 & 15 & 100 & \\
\hline
\end{tabular}

Tabel 2 menjelaskan bahwa hasil penelitian sebelum perlakuan didapatkan lebih dari setengah remaja pada kedua kelompok berpengetahuan cukup. Setelah diberikan masing-masing perlakuan, sebagian besar remaja pada kedua kelompok pendidikan kesehatan berada pada kategori berpengetahuan cukup.

Hasil penelitian didapatkan nilai uji beda Wilcoxon match pairs test didapatkan $\mathrm{p}$ value pada kelompok metode stratagem dengan media audiovisual adalah sebesar 0,014. Pengambilan keputusan dilakukan dengan melihat derajat kesalahan $(\alpha=0,05)$ dan karena $\mathrm{p}$ value $<0,05$ maka dapat disimpulkan Ha diterima yang berarti terdapat pengaruh yang sangat bermakna antara stratagem dan media audiovisualterhadap pengetahuan kesehatan reproduksi remaja di SMP Negeri 14 Jember. Pada kelompok pendidikan kesehatan metode konvensional ceramah $\mathrm{p}$ value sebesar 0,083 , karena $\mathrm{p}$ value >0,05 maka dapat disimpulkan $\mathrm{Ha}$ ditolak yang berarti tidak ada pengaruh antara metode konvensional ceramah terhadap pengetahuan kesehatan reproduksi remaja di SMP Negeri 14 Jember. Pengaruh stratagem dan media audiovisualterhadap pengetahuan kesehatan reproduksi remaja di SMPN 14 Jember dapat diketahui dengan menggunakan uji Wilcoxon.

Tabel 2. Pengetahuan Remaja Berdasarkan Indikator Pengetahuan Kesehatan Reproduksi Remaja Sebelum

\begin{tabular}{|l|c|c|c|c|}
\hline \multirow{2}{*}{\multicolumn{1}{|c|}{$\begin{array}{l}\text { Indikator } \\
\text { Pengetahuan }\end{array}$}} & \multicolumn{4}{|c|}{ Sebelum } \\
\cline { 2 - 5 } & $\begin{array}{c}\text { Kelompok } \\
\text { Stratagem } \\
\text { audiovisu } \\
\text { al }\end{array}$ & \multicolumn{2}{|c|}{$\begin{array}{c}\text { Kelompok } \\
\text { ceramah }\end{array}$} \\
\cline { 2 - 5 } & $\mathrm{n}$ & $\%$ & $\mathrm{n}$ & $\%$ \\
\hline $\begin{array}{l}\text { Pengetahuan } \\
\text { tentang organ- } \\
\text { organ reproduksi } \\
\text { pertanyaan). }\end{array}$ & 2 & 13,33 & 7 & 46,67 \\
\hline $\begin{array}{l}\text { Pengetahuan } \\
\text { tentang } \\
\text { pemeliharaan } \\
\text { organ-organ } \\
\text { reproduksi (3 } \\
\text { pertanyaan). }\end{array}$ & 9 & 57,78 & 7 & 46,67 \\
\hline $\begin{array}{l}\text { Pengetahuan } \\
\text { tentang kematangan } \\
\text { seksual (9 } \\
\text { pertanyaan). }\end{array}$ & 9 & 60 & 8 & 53,33 \\
\hline $\begin{array}{l}\text { Pengetahuan } \\
\text { tentang akibat } \\
\text { hubungan seksual } \\
\text { pada masa remaja } \\
\text { (8 pertanyaan). }\end{array}$ & 12 & 79,17 & 12 & 76,67 \\
\hline $\begin{array}{l}\text { Pengetahuan } \\
\text { tentang kekerasan } \\
\text { seksual (3 } \\
\text { pertanyaan). }\end{array}$ & 8 & 55,56 & 8 & 51,11 \\
\hline
\end{tabular}




\begin{tabular}{|l|c|c|c|c|}
\hline $\begin{array}{l}\text { Pengetahuan } \\
\text { tentang } \\
\text { keterampilan hidup } \\
(1 \text { pertanyaan). }\end{array}$ & 11 & 73,33 & 11 & 73,33 \\
\hline
\end{tabular}

Tabel 3. Pengetahuan Remaja Berdasarkan Indikator Pengetahuan Kesehatan Reproduksi Remaja Sesudah

\begin{tabular}{|c|c|c|c|c|}
\hline \multirow{3}{*}{$\begin{array}{c}\text { Indikator } \\
\text { Pengetahuan }\end{array}$} & \multicolumn{4}{|c|}{ Sesudah } \\
\hline & \multicolumn{2}{|c|}{$\begin{array}{l}\text { Kelompok } \\
\text { Stratagem } \\
\text { audiovisu } \\
\quad \text { al }\end{array}$} & \multicolumn{2}{|c|}{$\begin{array}{c}\text { Kelompok } \\
\text { ceramah }\end{array}$} \\
\hline & $\mathrm{n}$ & $\%$ & $\mathrm{n}$ & $\%$ \\
\hline $\begin{array}{l}\text { Pengetahuan } \\
\text { tentang organ- } \\
\text { organ reproduksi ( } 2 \\
\text { pertanyaan). }\end{array}$ & 4 & 26,67 & 8 & 53,33 \\
\hline $\begin{array}{l}\text { Pengetahuan } \\
\text { tentang } \\
\text { pemeliharaan } \\
\text { organ-organ } \\
\text { reproduksi ( } 3 \\
\text { pertanyaan). }\end{array}$ & 9 & 62,22 & 7 & 48,89 \\
\hline $\begin{array}{l}\text { Pengetahuan } \\
\text { tentang kematangan } \\
\text { seksual ( } 9 \\
\text { pertanyaan). }\end{array}$ & 9 & 61,48 & 8 & 56,30 \\
\hline $\begin{array}{l}\text { Pengetahuan } \\
\text { tentang akibat } \\
\text { hubungan seksual } \\
\text { pada masa remaja } \\
\text { (8 pertanyaan). }\end{array}$ & 13 & 84,17 & 12 & 80 \\
\hline $\begin{array}{l}\text { Pengetahuan } \\
\text { tentang kekerasan } \\
\text { seksual ( } 3 \\
\text { pertanyaan). }\end{array}$ & 9 & 60 & 8 & 55,56 \\
\hline $\begin{array}{l}\text { Pengetahuan } \\
\text { tentang } \\
\text { keterampilan hidup } \\
\text { (1 pertanyaan). }\end{array}$ & 15 & 100 & 11 & 73,33 \\
\hline
\end{tabular}

Tabel 2 dan 3 menjelaskan bahwa remaja sebelum diberikan pendidikan kesehatan metode stratagem dengan media audiovisual sebagian besar remaja mengetahui tentang pokok bahasan akibat hubungan seksual masa remaja. Hasil nilai posttest didapatkan bahwa remaja sesudah diberikan pendidikan kesehatan metode stratagem dengan media audiovisual terjadi peningkatan pengetahuan dalam indikator materi pendidikan kesehatan reproduksi remaja yakni, seluruh remaja mengetahui tentang keterampilan hidup.

Hasil penelitian pada kelompok remaja sebelum mendapatkan pendidikan kesehatan menggunakan metode konvensional ceramah diketahui sebagian besar remaja mengetahui tentang akibat hubungan seksual masa remaja. Hasil pengetahuan remaja setelah diberikan pendidikan kesehatan metode konvensional ceramah adalah remaja sebagian besar mengetahui tentang akibat hubungan seksual masa remaja dan keterampilan hidup.

Tabel 4. Perbedaan Pengetahuanremaja Tentang Kesehatan Reproduksi Remaja Sesudah Diberikan Intervensi Pada Kelompok Metode Ceramah Dan Kelompok Metode Stratagem Dengan Media Audiovisual

\begin{tabular}{|c|c|c|c|c|c|c|c|}
\hline \multirow{3}{*}{ Kelompok } & \multicolumn{6}{|c|}{ Pengetahuan } & \multirow{3}{*}{$\begin{array}{c}p \\
\text { value }\end{array}$} \\
\hline & \multicolumn{2}{|c|}{$\begin{array}{c}\text { Kuran } \\
\mathrm{g}\end{array}$} & \multicolumn{2}{|c|}{ Cukup } & \multicolumn{2}{|c|}{ Baik } & \\
\hline & $\mathrm{n}$ & $\%$ & $\mathrm{n}$ & $\%$ & $\mathrm{n}$ & $\%$ & \\
\hline $\begin{array}{l}\text { Metode } \\
\text { stratagem } \\
\text { dengan } \\
\text { media } \\
\text { audiovisual }\end{array}$ & 0 & 0 & 12 & 80 & 3 & 20 & 0,016 \\
\hline $\begin{array}{l}\text { Metode } \\
\text { Ceramah }\end{array}$ & 3 & 20 & 12 & 80 & 0 & 0 & \\
\hline
\end{tabular}

Tabel 4 menjelaskan bahwa hasil penelitian dengan uji statistik Mann Whitney didapatkan p value sebesar 0,016. Pengambilan keputusan dilakukan dengan melihat derajat kemaknaan $(\alpha=0,05)$. Nilai $\mathrm{p}$ value yang didapat dari hasil uji statistik adalah $\leq 0,05$ maka Ha diterima, artinya terdapat perbedaan pengaruh metode pendidikan kesehatan dengan 
stratagem media auidiovisual dan metode ceramah terhadap pengetahuan antara kelompok metode stratagem dengan media audiovisualdan kelompok metode ceramah di SMP Negeri 14 Jember.

\section{PEMBAHASAN}

Pengetahuan Remaja tentang Kesehatan Reproduksi Remaja Sebelum dan Sesudah Pendidikan Kesehatan dengan Cooperative Learning Tipe Group Cooperative Game: Stratagem Media Audiovisual

Pendidikan kesehatan berpengaruh terhadap pengetahuan remaja terhadap kesehatan reproduksi remaja yang diasumsikan karena penggunaan metode cooperative berkelompok yakni stratagem dengan media audiovisual mengenai kesehatan reproduksi remaja. Pengajaran yang baik bertujuan untuk menciptakan komunikasi yang efektif dan hasil pembelajaran yang tepat. Penggunaan media yang menyingkronkan dua media yakni media audio dan media visual yang dapat menimbulkan komunikasi dua arah antara pendidik dan peserta didik dalam proses belajar mengajar (Soetjiningsih, 2007).

Metode stratagem siswa dapat melakukan diskusi dan saling menanyakan sesuatu yang belum dimengerti sambil bermain dengan kelompok sebayanya tanpa tertekan dalam belajar karena permainan merupakan kegiatan yang ringan, menyenangkan dan kompetitif (Mubarak, Chayanti, Rozikin, dan Supradi, 2007). Pembelajaran dengan metode stratagem terjadi komunikasi dua arah. Mereka dapat menyelesaikan soal-soal dengan bekerja sama, berdiskusi dalam kelompok yang heterogen. Remaja yang pandai dan telah menyimpulkan hasil diskusi tersebut menjelaskan pada teman kelompoknya yang belum paham dan remaja mulai terbiasa mengkomunikasikan ide dan gagasannya dalam sebuah diskusi serta menyimpulkan ide dan gagasan orang lain.

Metode permainan ini mempunyai batas waktu dan aturan-aturan tertentu, dimana siswa dibagi menjadi beberapa kelompok yang saling berkompetisi untuk mencapai tujuan tertentu. Metode ini juga dapat membentuk keterampilan sosial dari peserta didik, sehingga dapat meningkatkan nilai-nilai sosial. Peneliti berpendapat bahwa teknik stratagem dan media audiovisual ini dapat meningkatkan motivasi remaja untuk belajar dan aktif mengemukakan pendapat sehingga dapat meningkatkan pengetahuan dari remaja. Media yang digunakan adalah audio visual yang menggabungkan media yang dapat didengar sekaligus dapat dilihat, sehingga komunikasi dapat ditangkap dalam dua indera, yakni pendengaran dan penglihatan. Hal ini meningkatkan motivasi dan komunikasi dalam pembelajaran menjadi menarik dan dapat dimengerti karena remaja tidak hanya mengerti, namun juga memiliki gambaran mengenai permasalahan kesehatan reproduksi remaja. Penerapan metode berkelompok sangat cocok digunakan pada remaja. Metode berkelompok dapat menjelaskan materi untuk menambah informasi atau materi baru kepada para remaja serta kegiatan berdiskusi dengan kelompok memiliki tujuan yaitu untuk melatih kerjasama dari para remaja danmembentuk nilai-nilai sosial dan kesetiakawanan sosial dalam kerjasama dengan kelompok (Universitas Kristen Satya Wacana, 2012). Remaja perkembangan psikososial menganggap bahwa memiliki kelompok atau dapat bekerjasama dengan orang lain adalah hal yang penting karena mereka akan menganggap bahwa dirinya merupakan bagian dari kelompok tersebut dan termotivasi dalam dirinya melalui kelompok (Yunita, 2009).

Gambaran hasil penelitian dapat diketahui bahwa remaja memiliki pengetahuan yang belum baik dalam 
kesehatan reproduksi remaja terutama mengenai organ-organ reproduksi sehingga remaja masih belum mengenali alat dan fungsi organ-organ reproduksinya, dan hasil penelitian dikaitkan dengan kasus drop out siswa akibat terjadinya pernikahan dini di sekolah tersebut, dapat diketahui bahwa masih belum siapnya remaja dalam melakukan pernikahan di usia dini. Kesehatan reproduksi adalah keadaan yang bukan hanya berorientasi terhadap terbebasnya dari penyakit atau kecacatan dalam semua hal yang berhubungan dengan sistem reproduksi namun keadaan sejahtera fisik, mental dan sosial secara menyeluruh yang berhubungan dengan sistem reproduksi, fungsi dan prosesnya. Seorang yang dikatakan kesehatan reproduksinya baik adalah ketika seseorang mampu memiliki kehidupan seks yang memuaskan, aman, dan memiliki kemampuan untuk bereproduksi serta bebas untuk memutuskan, kapan dan seberapa sering melakukannya (Inter-agency Working Group (IAWG) on Reproductive Health in Crises, 2010). Pengetahuan yang perlu diketahui remaja mengenai kesehatan reproduksi remaja adalah reproduksi yang bertanggungjawab, informasi persiapan pranikah yakni informasi yang diperlukan guna persiapan mental, dan emosional dalam kehidupan berkeluarga setelah menikah, serta kesiapan kehamilan, karena remaja akan menghadapi permasalahan kehamilan dalam masa berkeluarga (Depkes, 2008).

Remaja dalam hal ini harus memiliki pengetahuan dan sikap yang baik mengenai kesehatan reproduksinya karena kesehatan reproduksi mencakup keseluruhan reproduksi remaja dan sebelum mendapatkan kesehatan reproduksi remaja yang baik dan kehidupan seks yang memuaskan, serta aman, remaja seharusnya memiliki kemampuan dan pengetahuan mengenai organ, fungsi, proses, sehingga nanti mampu dalam memutuskan perihal aktivitas seksualnya.

Remaja belum siap dalam melakukan pernikahan pada usia dini. Remaja dalam usia dini masih dalam status emosi yang masih kurang stabil dan sering berubah-ubah, misalnya dalam waktu tertentu mereka mampu bahagia dan waktu lainnya mereka bisa marah ataupun menangis hingga menarik diri. Remaja dalam kejiwaannya lebih sensitif (mudah menangis, cemas, frustasi dan tertawa), agresif dan mudah bereaksi terhadap rangsangan luar yang berpengaruh (Wong, 2009). Secara keseluruhan, remaja pada usia pertengehan seharusnya tidak melakukan pernikahan dini karena dalam hal ini remaja masih belum siap dalam menentukan aktivitas seksualnya.

\section{Pengetahuan Remaja tentang Kesehatan Reproduksi Remaja Sebelum dan Sesudah diberikan Pendidikan Kesehatan dengan Metode Ceramah}

Tidak adanya pengaruh metode konvensial ceramah terhadap pengetahuan kesehatan reproduksi remaja di SMP Negeri 14 Jember. Metode ceramah merupakan sebuah bentuk interaksi komunikasi penyampaian materi pembelajaran secara verbal oleh pengajar kepada remaja yang dalam prosesnya sering terjadinya informasi yang kurang jelas karena biasanya hanya terjadi proses komunikasi satu arah yakni pengajar ke penerima dan pemberian gambaran mengenai materi yang diterangkan. Terjadinya banyak hambatan dalam komunikasi proses pembelajaran, salah satunya verbalisme, salah tafsir, gangguan pemahaman dan perhatian yang tidak berpusat. Verbalisme atau yang dapat diartikan bahwa remaja hanya mampu mengerti menyebutkan tanpa tahu arti dan maknanya (Palupi, 2014).

Kelas dengan metode ceramah yang merupakan metode konvensional, sering terjadinya komunikasi satu arah yang 
mengakibatkan kebiasaan remaja hanya terbiasa menunggu penjelasan dari pemberi materi (Santrock, 2007). Remaja dalam pembelajaran tidak punya inisiatif untuk melakukan komunikasi yang berhubungan dengan materi pembelajaran yang sedang berlangsung. Remaja mengalami kesulitan dalam mengkomunikasikan ide karena mereka khawatir jawabannya salah.

\section{Perbedaan Tingkat Pengetahuan Remaja tentang Kesehatan Reproduksi Remaja}

Terdapat perbedaan pengaruh metode pendidikan kesehatan dengan stratagem media auidiovisual dan metode ceramah terhadap pengetahuan kesehatan reproduksi remaja di SMP Negeri 14 Jember. Peneliti berasumsi bahwa terdapat pengalaman yang berbeda antara kedua kelompok tersebut. Faktor yang mempengaruhi dalam peningkatan pengetahuan adalah pengalaman (Mubarak, Chayanti, Rozikin, dan Supradi, 2007). Peneliti berasumsi bahwa perbedaan yang terjadi karena pengalaman yang berbeda yang dialami oleh kedua kelompok dalam penelitian ini. Pengalaman yang kurang baik cenderung akan membuat seseorang untuk melupakan, akan tetapi pengalaman yang menyenangkan akan suatu objek cenderung akan menimbulkankesan mendalam dan membekas dan akhirnya dapat membentuk sikap positif dalam kehidupannya. Pengalaman yang berbeda antara metode ceramah yang menggunakan metode satu arah, dan metode metode stratagem dengan media audiovisual stratagem media audiovisual yang mengedepankan komunikasi dua arah.

Pendidikan kesehatan melalui metode stratagem memberikan pengalaman menyenangkan bagi remaja karena pembelajaran permainan kelompok kooperatif stratagem ini didesain untuk mengubah gambaran bahwa belajar itu harus individual dan tidak dapat dilakukan sambil bermain. Permainan ini dilakukan secara berkelompok dengan membentuk kelompok-kelompok yang akan bersamasama berkompetisi melalui permainan kooperatif yang akan menimbulkan proses berpikir remaja, jiwa kompetitif remaja, dan komunikasi bagi remaja. Media audiovisual dalam pendidikan kesehatan memberikan pengalaman berkesan bagi remaja. Media audiovisual dapat memberikan kesan yang mendalam dan efisien dalam penggunaan waktu serta dapat menjadi fokus remaja saat pendidikan kesehatan, yang mampu mempengaruhi pengetahuan dan sikap remaja.

Metode konvensional memberikan pengalaman memberikan kesan kurang menyenangkan sehingga muncul kecenderungan tidak mengingat pokok pembahasan. Salah satu hal yang terjadi pada penelitian adalah gangguan pemahaman, perhatian yang tidak berpusat atau teralihkan, munculnya verbalisme, salah tafsir dan tidak terjadinya proses berpikir logis. Sedikit terjadinya proses berpikir, tidak munculnya jiwa kompetitif, dan komunikasi pada remaja karena dalam proses belajar mengajar remaja tidak mendapatkan peran banyak dalam metode ini.

Remaja dengan pendidikan kesehatan metode stratagem dengan media audiovisual memiliki pengetahuan yang lebih baik dan siap untuk mencegah diri dari masalah kesehatan reproduksi remaja dan memungkinkan untuk terhindar dari masalah kesehatan reproduksi remaja seperti pernikahan dini, kehamilan di luar nikah dan seks bebas. Terjadinya perilaku seksual pada remaja tergantung dari pengetahuan yang dimiliki remaja, sehingga semakin baik pengetahuan remaja mengenai hubungan seksual maka kecenderungan remaja untuk menghidari perilaku-perilaku masalah kesehatan reproduksi di kalangan remaja, dan sebaliknya pada remaja yang kurang mengetahui maka kecenderungannya akan 
mendekati kea rah perilaku-perilaku beresiko tersebut (Santayasa, 2007; Santrock, 2013).

Remaja terjadi perbedaan peningkatan pengetahuan pada indikator pengetahuan organ-organ reproduksi, dimana remaja pada kelompok stratagem audiovisual mengalami peningkatan $13,34 \%$ dan $6,66 \%$ pada remaja kelompok ceramah. Perbedaan terjadi karena remaja pada kelompok stratagem audiovisual mendapatkan gambaran baik secara visual maupun audio, sehingga terjadi peningkatan lebih tinggi dari metode ceramah yang sulit mengilustrasikan mengenai organ-organ reproduksi. Salah tafsir dapat terjadi pada ceramah karena metode konvensional ceramah hanya mampu menjelaskan tanpa mampu mengilustrasikan dan memberikan remaja untuk menjelaskan dan mempraktekkan langsung mengenai pembelajaran yang diterangkan (Mertia, Hidayat, dan Yuliadi, 2011).

\section{KESIMPULAN}

Kesimpulan dari hasil penelitian adalah adanya pengaruh yang bermakna antara pendidikan kesehatan metode stratagem dan media audiovisual terhadap pengetahuan kesehatan reproduksi remaja dan adanya perbedaan pengaruh metode pendidikan kesehatan dengan stratagem media auidiovisual dan metode ceramah terhadap pengetahuan antara kelompok eksperiment dan kelompok kontrol.

\section{SARAN}

Hasil ini menunjukkan bahwa pendidikan kesehatan dengan metode stratagem media audiovisual dapat di diberikan kepada remaja untuk meningkatkan pengetahuan remaja mengenai kesehatan reproduksi remaja. Rekomendasi penelitian ini adalah membentuk kelompok peduli kesehatan reproduksi remaja yang berperan aktif dalam pencegahan masalah kesehatan reproduksi remaja dengan metode cooperative.

\section{UCAPAN TERIMA KASIH}

Peneliti menyampaikan terima kasih kepada remaja, dan masyarakat di SMP Negeri 14 Jember yang membantu peneliti dalam melaksanakan penelitian.

\section{KEPUSTAKAAN}

Arikunto S, 2006. Prosedur penelitian: suatu pendekatan praktik. Jakarta: Rineka Cipta.

BKKBN, 2011. Policy brief pusat penelitian dan pengembangan kependudukan. 2011. (Online) http://www.bkkbn.go.id/litbang/pusd $\mathrm{u} /$ Hasi1\%20Penelitian/Karakteristik\% 20Demografis/2011/Kajian\%20Profil $\%$ 20Penduduk\%20Remaja\%20(10\% 20-\%2024\%20tahun).pdf (diambil tanggal 19 Januari 2015).

Centers for Disease Control (CDC), 2013. (Online)

http://www.cdc.gov/HealthyYouth/se xualbehaviors/._(Diambil tanggal 20 Februari 2015).

Depkes, 2008. Pedoman operasional pelayanan terpadu kesehatan reproduksi di Puskesmas. Jakarta: Depkes.

Inter-agency Working Group (IAWG) on Reproductive Health in Crises, 2010. Buku pedoman lapangan antar lembaga kesehatan reproduksi dalam situasi darurat bencana. Australia: Inter-agency Working Group on Reproductive Health in Crises.

Laksmiwati IAA. 2013. Transformasi sosial dan perilaku reproduksi remaja. [internet]. 2008. [Diambil tanggal 23 Mei 2015] dari: http://ejournal.unud.ac.id/

Mertia I, Hidayat T, Yuliadi EN, 2011. Hubungan antara pengetahuan seksualitas dan kualitas komunikasi orang tua dan anak dengan perilaku 
seks bebas pada remaja siswa-siswi MAN Gondangrejo Karanganyar.

Mubarak WI, Chayanti N, Rozikin K, Supradi, 2007. Promosi kesehatan, sebuah pengantar proses belajar mengajar dalam pendidikan. Yogyakarta: Graha Ilmu.

Nursalam, Effendi F, 2008. Pendidikan dalam keperawatan. Jakarta: Salemba Medika.

Palupi D. C. A, 2014. Pengaruh teknik talking stick terhadap pengetahuan dan sikap dalam pencegahan hiv/aids pada remaja di SMP Negeri 1 Puger Kabupaten Jember.

Rianto et al, 2006. Pendekatan, strategi, dan metode pembelajaran. Malang: Depdiknas.

Santayasa, IW, 2007. Landasan Konseptual Media Pembelajaran. Singaraja: Universitas Pendidikan Ganesha.

Santrock JW, 2007. Remaja Jilid 1 Edisi 11. Jakarta : Erlangga.

Soetjiningsih, 2007. Tumbuh kembang remaja dan permasalahannya. Jakarta: CV. Sagung Seto.

Susilana R, Riyana C, 2009. Media pembelajaran hakikat pengembangan, pemanfaatan, dan penilaian. Bandung: Wacana Prima.

Universitas Kristen Satya Wacana, 2012. Efektifitas penggunaan media audio visual (VCD pembelajaran) berdasarkan teori Bruner dalam pembelajaran matematika siswa kelas IV SD Negeri 1 Mojowetan Kecamatan Banjarejo Kabupaten Blora Semester II tahun Pelajaran 2011/2012.

Wong et al, 2009. Buku ajar keperawatan pediatrik. Volume 1. Jakarta: EGC.

Yunita A., 2009. Pengaruh penerapan metode stratagem melalui pembelajaran kooperatif terhadap kemampuan komunikasi matematika siswa kelas VIII SMP Negeri 20 Padang. Padang: STKIP PGRI. 